\title{
ABSES HEPAR : SEBUAH LAPORAN KASUS
}

\author{
${ }^{1)}$ Mahendra, ${ }^{2)}$ Anggi Dwi Prasetyo \\ ${ }^{1)}$ Rumah Sakit Daerah Madani Kota Pekanbaru \\ 1) Jl. Garuda Sakti, Simpang Baru, Tampan, Kota Pekanbaru, Riau 28291 \\ ${ }^{2)}$ Program Studi Pendidikan Dokter, Fakultas Kedokteran, Universitas Abdurrab \\ ${ }^{2)}$ Jl. Riau Ujung No. 73 Pekanbaru - Riau - Indonesia \\ E-mail : ${ }^{1)}$ dr.mahens@gmail.com, ${ }^{2}$ anggidprasetyo@univrab.ac.id
}

\section{Kata Kunci:}

Abses hepar, piogenik, lobus

sinistra,

laparoskopi

\section{Keywords:}

Liver abscess, pyogenic, left lobe, drainage, laparoscopy

\section{Info Artikel}

Tanggal dikirim: 15-1-2021

Tanggal direvisi: 22-1-2021

Tanggal diterima: 29-1-2021

DOI Artikel:

10.36341/cmj.v4i1.2138

Attribution-NonCommercial

4.0 International. Some rights

reserved

\begin{abstract}
ABSTRAK
Abses hepar adalah salah satu bentuk infeksi yang paling sering terjadi pada hepar. Salah satu bentuk abses hepar yang paling sering terjadi adalah abses hepar piogenik, yang umumnya ditemukan pada lobus kanan hepar. Kami melaporkan kasus abses hepar yang terjadi pada lobus kiri hepar, dengan keluhan yang tidak spesifik. Pasien datang hanya dengan keluhan perut yang membengkak, tanpa disertai keluhan lain. Pemeriksaan radiologis berupa CT-Scan mengkonfirmasi diagnosis abses hepar lobus sinistra. Pasien ditangani dengan tindakan drainase abses per laparoskopi. Tidak ada komplikasi yang ditemukan selama dan pasca operasi. Kasus ini menunjukkan bahwa diperlukan kecurigaan yang tinggi untuk abses hepar pada pasien dengan keluhan abdomen yang tidak spesifik. Drainase abses per laparoskopi yang dikombinasikan dengan terapi antibiotik merupakan pendekatan terapi yang aman dan efektif untuk kasus seperti ini.
\end{abstract}

\begin{abstract}
Liver abscess is one of the most common forms of infection in the liver. One of the most common forms of liver abscess is a pyogenic liver abscess, which is commonly found in the right lobe of the liver. We report a case of a liver abscess occurring in the left lobe of the liver, with a non-specific complaint. The patient came only with complaints of a swollen abdomen, without any other complaints. Radiological examination in the form of CT-Scan confirmed the diagnosis of left lobe liver abscess. The patient was treated with laparoscopic abscess drainage. No intraoperative or postoperative complications were found. This case demonstrates the need for high suspicion of liver abscess in a patient with non-specific abdominal complaints. Laparoscopic drainage of the abscess in combination with antibiotic therapy is a safe and effective therapeutic approach for such cases.
\end{abstract}

\section{PENDAHULUAN}

Abses hepar adalah salah satu bentuk infeksi pada hepar, yang ditandai oleh terdapatnya pus yang diselubungi oleh jaringan fibrosa pada parenkim hepar. Kondisi ini merupakan salah satu infeksi hepar yang mengancam jiwa, terutama jika tidak ditangani dengan baik. Tiga bentuk abses hepar yang paling umum adalah abses hepar piogenik (terkait infeksi bakteri), amebik (terkait infeksi protozoa spesies Entamoeba), dan fungal (terkait infeksi jamur) [1].

Prevalensi dan insidensi abses hepar bervariasi berdasarkan jenis kelamin, etiologi, dan tingkat pendapatan suatu negara. Pada penelitian yang dilakukan selama 35 tahun di Olmsted County, Minessota, Amerika Serikat, insidensi abses hepar yang ditemukan adalah 2,09-3,63 kasus per 100.000 populasi per tahun, dengan tingkat mortalitas sebesar 16,8\% dalam 6 bulan. Insidensi pada laki-laki ditemukan lebih tinggi daripada perempuan (3,92 kasus per 100.000 populasi per tahun vs 1,87 kasus per 100.000 populasi per tahun [2]. Penelitian retrospektif menemukan bahwa abses hepar piogenik lebih umum dialami pada perempuan yang berusia lebih dari 65 tahun [3]. Penelitian single centre yang terdiri dari 109 sampel di Italia menemukan bahwa sebagian besar 
pasien adalah laki-laki (62 vs 47 pasien), dengan usia rata-rata 65,4 tahun (kisaran 1892 tahun) [4]. Di negara berkembang, dari 150 pasien abses hepar selama 2011-2015, sebagian besar pasien menderita abses hepar piogenik [5].

Terdapat beberapa manifestasi klinis yang dapat muncul pada abses hepar. Manifestasi klinis yang dilaporkan oleh pasien dapat berupa menggigil, diare, hepatomegali, demam, nyeri abdomen, ikterus, mual muntah, astenia, penurunan berat badan, sesak dan batuk, kondisi umum yang kurang baik, serta kebingungan [2-5]. Manifestasi klinis yang paling umum adalah nyeri abdomen [5] dan demam [3, 4, 6].

Temuan radiologi yang paling umum adalah double target sign, baik pada abses hepar piogenik maupun abses hepar amebik, yang ditemukan berdasarkan pemeriksaan CT. Tanda lain yang dapat ditemukan pada abses hepar piogenik adalah cluster sign [7]. Lesi umumnya terdapat pada lobus kanan hepar, namun dapat ditemukan juga lesi pada lobus kiri dan lobus kaudatus [5, 8,9]. Abses hepar pada lobus kiri memerlukan perhatian khusus dan penanganan yang cepat, karena risiko ruptur ke perikardium sangat besar [10].

Kami melaporkan kasus abses hepar, yang berlokasi di lobus kiri hepar pasien. Pada kasus ini, pasien tidak melaporkan keluhan apapun selain bengkak di daerah perutnya. Pasien berhasil ditangani dengan tindakan drainase abses per laparoskopi. Kasus ini menunjukkan pentingnya memiliki kecurigaan yang tinggi terhadap abses hepar, khususnya pada pasien yang hanya mengeluhkan perut membengkak, tanpa gejala lain yang umumnya dikeluhkan pada kasus abses hepar.

\section{LAPORAN KASUS Anamnesis}

Pasien laki-laki berusia 60 tahun datang ke Poli Bedah Rumah Sakit (RS) Santa Maria Pekanbaru, Provinsi Riau, Indonesia dengan keluhan bengkak di perut. Keluhan ini sudah pasien alami selama kurang lebih satu bulan. Selain bengkak di perut, tidak ada hal lain yang dikeluhkan oleh pasien.

\section{Pemeriksaan Fisik}

Pada pemeriksaan keadaan umum, ditemukan bahwa pasien komposmentis dan tampak sakit sedang. Pemeriksaan tanda vital menujukkan bahwa suhu tubuh pasien $37,6^{\circ} \mathrm{C}$, tekanan darah $130 / 90$ $\mathrm{mmHg}$, denyut nadi $64 \mathrm{kali} / \mathrm{menit}$, dan frekuensi napas $20 \mathrm{kali} / \mathrm{menit}$. Selain itu, ditemukan bahwa konjungtiva pasien anemis namun tidak ikterik. Tidak ditemukan perbesaran kelenjar getah bening. Hasil pemeriksaan paru dan jantung dalam batas normal.

Pada pemeriksaan abdomen, ditemukan bahwa abdomen mengalami distensi. Bising usus dalam batas normal. Ketika dilakukan palpasi, hepar teraba membesar, dengan permukaan licin dan teraba adanya fluktuasi. Selain itu, ditemukan juga nyeri tekan pada regio epigastrium dan Ludwig sign positif.

\section{Pemeriksaan Penunjang}

Kami melakukan pemeriksaan laboratorium pada pasien. Pemeriksaan hematologi menunjukkan anemia normositik normokrom (hemoglobin 8,3 $\mathrm{g} / \mathrm{dL}$ dan MCV, MCH, MCHC dalam batas normal). Selain itu, ditemukan juga leukositosis $\left(11,48 \times 10^{3} / \mu 1\right)$. Komponen hematologi lainnya dalam batas normal. Hasil pemeriksaan dapat dilihat di Tabel 1.

\section{Tabel 1. Hasil Pemeriksaan Laboratorium}

\begin{tabular}{|c|c|c|c|}
\hline Pemeriksaan & Hasil & Satuan & $\begin{array}{l}\text { Nilai } \\
\text { normal }\end{array}$ \\
\hline \multicolumn{4}{|l|}{ Hematologi } \\
\hline \multicolumn{4}{|l|}{ Darah lengkap } \\
\hline - Hemoglobin & 8.3 & $\mathrm{~g} / \mathrm{dL}$ & $\begin{array}{l}13.5- \\
17.5\end{array}$ \\
\hline - Hematokrit & 24.2 & $\%$ & $\begin{array}{l}41.0- \\
53.0\end{array}$ \\
\hline - Leukosit & 11.48 & $10^{\wedge} 3 / \mu 1$ & $\begin{array}{l}4.10- \\
10.90\end{array}$ \\
\hline - $\mathrm{RBC}$ & 3.02 & $10^{\wedge} 3 / \mu 1$ & $\begin{array}{l}4.50- \\
5.90\end{array}$ \\
\hline - Trombosit & 381 & $10^{\wedge} 3 / \mu 1$ & $\begin{array}{l}140- \\
440\end{array}$ \\
\hline - $\mathrm{MCV}$ & 80.1 & $\mathrm{fL}$ & $80.0-$ \\
\hline
\end{tabular}




\begin{tabular}{|c|c|c|c|}
\hline \\
\hline & & & 100.0 \\
\hline - $\mathrm{MCH}$ & 27.5 & $\mathrm{pg}$ & $\begin{array}{l}26.0- \\
34.0\end{array}$ \\
\hline - $\mathrm{MCHC}$ & 34.3 & $\mathrm{~g} / \mathrm{dL}$ & $\begin{array}{l}31.0- \\
36.0\end{array}$ \\
\hline - $\quad \mathrm{RDW}-\mathrm{CV}$ & 16.5 & $\%$ & $\begin{array}{l}11.6- \\
14.8\end{array}$ \\
\hline \multicolumn{4}{|l|}{ Diff } \\
\hline - N. Segmen & 79.40 & $\%$ & $\begin{array}{l}47.00- \\
80.00\end{array}$ \\
\hline - $\quad$ Limfosit & 10.00 & $\%$ & $\begin{array}{l}13.00- \\
40.00\end{array}$ \\
\hline - Monosit & 10.20 & $\%$ & $\begin{array}{l}2.00- \\
11.00\end{array}$ \\
\hline - $\quad$ Eosinofil & 0.10 & $\%$ & $\begin{array}{l}0.00- \\
2.00\end{array}$ \\
\hline - $\quad$ Basofil & 0.30 & $\%$ & $\begin{array}{l}0.00- \\
2.00\end{array}$ \\
\hline $\begin{array}{l}\text { Neutrofil Limphocyte } \\
\text { Ratio }\end{array}$ & 7.94 & & $<3.13$ \\
\hline $\begin{array}{l}\text { Absolute Limphocyte } \\
\text { Count }\end{array}$ & 1.150 & $/ \mu 1$ & $>1.500$ \\
\hline $\mathrm{CT}$ & $5,30 "$ & menit & $1-6$ \\
\hline BT & 1'30" & menit & $1-3$ \\
\hline \multicolumn{4}{|l|}{ Kimia Klinik } \\
\hline SGOT/AST & 54 & $\mathrm{U} / \mathrm{L}$ & $10-50$ \\
\hline SGPT/ALT & 62 & $\mathrm{U} / \mathrm{L}$ & $<41$ \\
\hline Bilirubin Total & 0,81 & $\mathrm{mg} / \mathrm{dL}$ & $\begin{array}{l}0.10- \\
1.20\end{array}$ \\
\hline Glukosa darah sewaktu & 96 & $\mathrm{mg} / \mathrm{dL}$ & $70-140$ \\
\hline Ureum & 18 & $\mathrm{mg} / \mathrm{dL}$ & $15-39$ \\
\hline Kreatinin & 0.7 & $\mathrm{mg} / \mathrm{dL}$ & $0.6-1.3$ \\
\hline
\end{tabular}
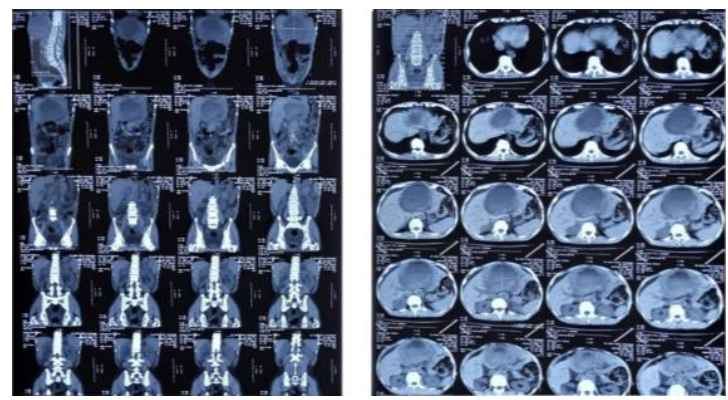

Gambar 1. Hasil CT-Scan Abdomen

\section{Tatalaksana dan Tindak Lanjut}

Berdasarkan hasil pemeriksaan, ditegakkan diagnosis kerja abses hepar lobus sinistra. Pasien kemudian direncanakan untuk menjalani tindakan drainase abses per laparoskopi. Tidak ada kesulitan atau kelainan lain yang ditemukan selama tindakan (Gambar 2).

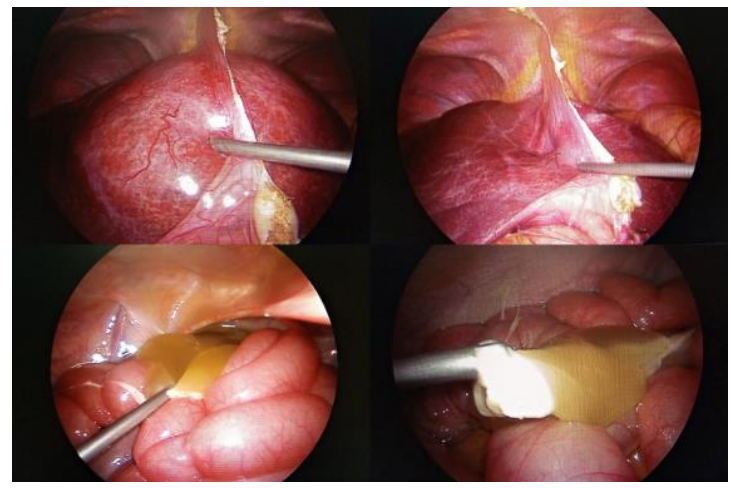

Gambar 2. Drainase Abses per Laparoskopi

Pada pemeriksaan fungsi hepar, ditemukan peningkatan aspartate aminotransferase (AST) dan alanine aminotransferase (ALT), masing-masing 54 dan 62 IU/L. Kadar bilirubin total dalam batas normal. Hasil pemerikaan glukosa darah sewaktu, ureum, dan kreatinin juga dalam batas normal.

Hasil pemeriksaan CT-Scan abdomen (Gambar 1) menunjukkan hepar membesar terutama di lobus sinistra, dan ditemukan nodul hipodens dengan rim hiperdens pada lobus sinistra hepar, berukuran $9,7 \mathrm{~cm}$ x $12 \mathrm{~cm}$. Selain itu, tidak ada kelainan lain yang ditemukan pada pemeriksaan ini.
Setelah tindakan dilakukan, spesimen kemudian dikirim ke laboratorium untuk diperiksa lebih lanjut. Hasil kultur spesimen pus menunjukkan bahwa tidak ditemukan pertumbuhan bakteri pathogen pada spesimen. Hasil pemeriksaan histopatologi/sitopatologi spesimen dinding abses mendukung diagnosis klinis abses hepar.

Setelah operasi, pasien dirawat inap selama tiga hari dan mendapatkan terapi antibiotik berupa ceftriaxone dan metronidazole intravena (IV) dan analgesik berupa ketorolac IV. Pasien juga menjalani pemeriksaan darah lengkap, yang hasilnya dapat dilihat pada Tabel 2 . Pasien kemudian dipulangkan, dan diresepkan Cefixime 2x200 mg, 
metronidazole $3 \times 500 \mathrm{mg}$, ibuprofen $3 \times 400$ $\mathrm{mg}$, dan ranitidine $2 \times 150 \mathrm{mg}$ per oral (PO). Pasien kembali untuk kontrol satu minggu kemudian, luka sudah menutup dengan baik, dan tidak ditemukan komplikasi apapun pada pasien.

\section{Tabel 2. Hasil Pemeriksaan Laboratorium Pasca Tindakan}

\begin{tabular}{|c|c|c|c|}
\hline Pemeriksaan & $\begin{array}{l}\text { Hasi } \\
1\end{array}$ & Satuan & $\begin{array}{l}\text { Nilai } \\
\text { Rujuka } \\
\text { n }\end{array}$ \\
\hline \multicolumn{4}{|l|}{ Hematologi } \\
\hline \multicolumn{4}{|l|}{ Darah lengkap } \\
\hline - Hemoglobin & 10.1 & $\mathrm{~g} / \mathrm{dL}$ & $\begin{array}{l}13.5- \\
17.5\end{array}$ \\
\hline - Hematokrit & 29.1 & $\%$ & $\begin{array}{l}41.0- \\
53.0\end{array}$ \\
\hline - Leukosit & $\begin{array}{l}20.0 \\
2\end{array}$ & $10^{\wedge} 3 / \mu$ & $\begin{array}{l}4.10- \\
10.90\end{array}$ \\
\hline - $\mathrm{RBC}$ & 3.71 & $\begin{array}{l}10^{\wedge} 3 / \mu \\
1\end{array}$ & $\begin{array}{l}4.50- \\
5.90\end{array}$ \\
\hline - $\quad$ Trombosit & 373 & $10^{\wedge} 3 / \mu$ & $140-440$ \\
\hline - $\mathrm{MCV}$ & 78.4 & $\mathrm{fL}$ & $\begin{array}{l}80.0- \\
100.0\end{array}$ \\
\hline - $\mathrm{MCH}$ & 27.2 & $\mathrm{pg}$ & $\begin{array}{l}26.0- \\
34.0\end{array}$ \\
\hline - $\mathrm{MCHC}$ & 34.7 & $\mathrm{~g} / \mathrm{dL}$ & $\begin{array}{l}31.0- \\
36.0\end{array}$ \\
\hline - $\quad \mathrm{RDW}-\mathrm{CV}$ & 16.3 & $\%$ & $\begin{array}{l}11.6- \\
14.8\end{array}$ \\
\hline \multicolumn{4}{|l|}{ Diff } \\
\hline - N. Segmen & $\begin{array}{l}90.2 \\
0\end{array}$ & $\%$ & $\begin{array}{l}47.00- \\
80.00\end{array}$ \\
\hline - Limfosit & 4.80 & $\%$ & $\begin{array}{l}13.00- \\
40.00\end{array}$ \\
\hline - Monosit & 4.90 & $\%$ & $\begin{array}{l}2.00- \\
11.00\end{array}$ \\
\hline - Eosinofil & 0.00 & $\%$ & $\begin{array}{l}0.00- \\
2.00\end{array}$ \\
\hline - $\quad$ Basofil & 0.10 & $\%$ & $\begin{array}{l}0.00- \\
2.00\end{array}$ \\
\hline $\begin{array}{l}\text { Neutrofil Limphocyte } \\
\text { Ratio }\end{array}$ & $\begin{array}{l}18.7 \\
9\end{array}$ & & $<3.13$ \\
\hline $\begin{array}{l}\text { Absolute Limphocyte } \\
\text { Count }\end{array}$ & 970 & $/ \mu 1$ & $>1.500$ \\
\hline
\end{tabular}

\section{PEMBAHASAN}

Hingga saat ini, abses hepar merupakan kasus yang masih sering dijumpai. Kasus abses hepar yang berlokasi di lobus kiri merupakan kasus yang jarang, karena pada umumnya abses dijumpai pada lobus kanan hepar [10].
Seperti yang telah dibahas sebelumnya, beberapa gejala yang mungkin ditemukan pada pasien suspek abses hepar meliputi menggigil, diare, hepatomegali, demam, nyeri abdomen, ikterus, mual muntah, astenia, penurunan berat badan, sesak dan batuk, kondisi umum yang kurang baik, serta kebingungan, dimana gejala yang paling umum dilaporkan adalah nyeri abdomen dan demam [2-5]. Pada kasus ini, pasien hanya melaporkan perut membengkak saja, tanpa adanya gejala yang lain. Dalam hal ini pemeriksaan radiologis memiliki peran yang sangat penting dalam penegakkan diagnosis. Pemeriksaan ultrasonografi abdomen dan CT-Scan merupakan teknik pencitraan yang sangat berguna dalam mendiagnosis abses hepar, dimana gambaran yang ditemukan dikenal sebagai double target sign [11]. Pasien dalam kasus ini menjalani pemeriksaan CT-Scan, yang mengungkapkan adanya nodul hipodens dengan rim hiperdens pada lobus sinistra hepar, yang sejalan dengan gambaran abses hepar.

Pada situasi tertentu, dapat juga muncul gambaran atipikal dari abses hepar, yaitu ditemukannya enhancement dari septa interna atau multi-circumferential enhancement. Jika muncul gambaran seperti ini, sulit untuk secara akurat mendiagnosis abses hepar, karena metastasis hepar yang mengalami nekrosis sentral dapat memiliki gambaran seperti ini. Pada kondisi ini, single energy CT tradisional akan sulit menegakkan diagnosis abses hepar. Peran MRI dalam kondisi seperti sangat berguna dalam membedakan lesi metastatis hepar dan lesi abses hepar. Selain MRI, dual energy CT juga memiliki akurasi diagnostik yang tinggi dalam membedakan abses hepar dari metastasis hepar $[12,13]$.

Langkah selanjutnya yang harus diperhatikan dalam penegakan diagnosis abses hepar adalah menentukan kemungkinan jenis abses hepar yang terjadi, karena akan berimplikasi pada modalitas terapi yang digunakan. Dua 
bentuk abses hepar yang paling sering ditemukan adalah abses hepar piogenik/pyogenic liver abscess (PLA) dan abses hepar amebik/amebic liver abscess (ALA). Gejala saja akan sulit untuk membedakan kedua jenis abses hepar tersebut. ALA biasanya banyak ditemukan di negara berpendapatan menengah hingga rendah, pada pria usia 30-50 tahun, dan terkait dengan sanitasi yang buruk, sedangkan PLA terjadi secara global dan ditemukan pada pasien yang usianya lebih tua, serta terkait dengan patologi bilier yang mendasari [11].

Perlu diperhatikan juga bahwa abses hepar dapat disebabkan oleh penyebaran infeksi intra-abdomen. Kondisi ini merupakan kasus yang jarang terjadi, namun tetap harus diperhitungkan ketika akan menentukan jenis atau etiologi dari abses hepar. Contoh kasus dari kondisi ini adalah adanya benda asing yang menyebabkan perforasi saluran gastrointestinal atau adanya perforasi apendiks yang menciptakan fistula langsung ke hepar $[14,15]$. Satu penelitian melaporkan kasus ruptur gas-forming pyogenic liver abscess (GFPLA) yang muncul sebagai peritonitis dengan gambaran pneumoperitoneum tanpa adanya ruptur saluran gastrointestinal, yang merupakan kondisi mengancam jiwa yang memerlukan perhatian khusus [16].

Terdapat beberapa modalitas terapi untuk abses hepar, yang meliputi terapi medikamentosa dan tindakan bedah seperti drainase abses per laparoskopi atau drainase abses terbuka, [17-19, 21] hingga hepatektomi pada kasus abses hepar multilokuler [20]. Pendekatan terapi untuk ALA dapat berupa pendekatan terapi medikamentosa, sedangkan untuk PLA dan kombinasi infeksi memerlukan aspirasi berulang atau drainase abses di samping terapi medikamentosa [11]. Rekomendasi terkini menyatakan bahwa abses hepar yang berukuran kurang dari $3 \mathrm{~cm}$ dapat ditangani dengan farmakoterapi [17]. Pada kasus ini, abses berukuran $9,7 \mathrm{~cm} \times 12 \mathrm{~cm}$ sehingga memerlukan pendekatan non- farmakoterapi. Pasien ditangani dengan drainase abses per laparoskopi, selain terapi medikamentosa.

Terdapat berbagai laporan yang menggunakan teknik drainase per laparoskopik untuk abses hepar. Satu studi melaporkan abses hepar pada pasien lanjut usia dalam kondisi imunosupresif, yang ditangani dengan drainase abses per laparoskopik, menunjukkan hasil yang baik, tanpa adanya komplikasi operasi, dan pasien dipulangkan dari rumah sakit 7 hari pasca operasi [18]. Seri kasus yang terdiri dari 32 kasus di Vietnam juga menemukan bahwa drainase abses per laparoskopi untuk abses hepar adalah pendekatan terapi yang sangat efektif, terutama untuk abses besar dan abses yang mengalami ruptur, dan berdampak positif pada penurunan angka mortalitas, penyembuhan pascaoperasi, dan minim komplikasi [19]. Satu penelitian yang membandingkan drainase abses per laparoskopi dengan drainase terbuka yang dilakukan pada 48 PLA kompleks (22 pasien menjalani drainase per laparoskopi, 26 pasien menjalani drainase terbuka) menyimpulkan bahwa kedua teknik merupakan pendekatan yang aman dan efektif. Masing-masing memiliki kelebihan tersendiri yaitu, drainase abses per laparoskopi membutuhkan waktu operasi yang lebih singkat, dan menurunkan angka morbiditas dan lama perawatan di rumah sakit, sedangkan drainase terbuka merupakan terapi pilihan untuk pasien dengan sepsis berat atau pasien yang gagal diterapi dengan teknik drainase perkutan [19].

\section{KESIMPULAN}

Abses hepar merupakan salah satu penyakit infeksi hepar yang paling sering ditemui, dan berpotensi mengancam jiwa jika tidak terdiagnosis dan tidak ditangani dengan baik. Diperlukan kecurigaan yang tinggi pada abses hepar terutama untuk pasien-pasien yang datang dengan keluhan abdomen yang tidak spesifik, yang disertai dengan perut yang membengkak. Pendekatan pencitraan seperti CT-Scan dan 
ultrasonografi abdomen memiliki peran yang sangat penting dalam penegakan diagnosis abses hepar. Pendekatan terapi pada abses hepar terdiri dari terapi medikamentosa dan terapi surgikal. Terapi surgikal pada abses hepar, khususnya drainase abses per laparoskopi merupakan terapi yang relatif aman dan efektif dalam pengelolaan abses hepar, serta dapat menurunkan angka morbiditas dan mortalitas abses hepar.

\section{DAFTAR PUSTAKA}

[1] W. Mohammad Ali, I. Ali, R. SAA, R. AZ and M. Ahmed, "Recent Trends in the Epidemiology of Liver Abscess in Western Region of Uttar Pradesh: A Retrospective Study", Journal of Surgery and Anesthesia, vol. 02, no. 02, pp. 1-4, 2018. Tersedia: https://www.longdom.org/openaccess/recent-trends-in-the-epidemiologyof-liver-abscess.pdf.
September 2021].

[Diakses

10

[2] A. Sharma, S. Mukewar, K. Mara, R. Dierkhising, P. Kamath and N. Cummins, "Epidemiologic Factors, Clinical Presentation, Causes, and Outcomes of Liver Abscess: A 35-Year Olmsted County Study", Mayo Clinic Proceedings: Innovations, Quality \& Outcomes, vol. 2, no. 1, pp. 16-25, 2018, doi: 10.1016/j.mayocpiqo.2018.01.002

[3] J. Peris et al., "Clinical and Epidemiological Characteristics of Pyogenic Liver Abscess in People 65 Years or Older versus People Under 65: A Retrospective Study", BMC Geriatrics, vol. 17, no. 1, pp. 1-9, 2017, doi: 10.1186/s12877-017-0545-x

[4] C. Serraino et al., "Characteristics and Management of Pyogenic Liver Abscess: A European Experience", Medicine, vol. 97, no. 19, pp. 1-6, 2018, doi: 10.1097/MD.0000000000010628

[5] F. Reyna-Sepúlveda et al., "Epidemiology and Prognostic Factors of Liver Abscess Complications in Northeastern Mexico", Medicina Universitaria, vol. 19, no. 77, pp.
178-183, 2021,

doi: 10.1016/j.rmu.2017.10.009

[6] W. Wang, Z. Tao and H. Wu, "Etiology and Clinical Manifestations of Bacterial Liver Abscess", Medicine, vol. 97, no. 38, pp. $\quad 1-4, \quad 2018, \quad$ doi 10.1097/MD.0000000000012326

[7] S. Malekzadeh, L. Widmer, F. Salahshour, B. Egger, M. Ronot and H. Thoeny, "Typical Imaging Finding of Hepatic Infections: A Pictorial Essay", Abdominal Radiology, vol. 46, no. 2, pp. 544-561, 2020, doi: 10.1007/s00261-020-02642-z

[8] S. Sharma and V. Ahuja, "Liver Abscess: Complications and Treatment", Clinical Liver Disease, vol. 46, no. 2, pp. 544-561, 2021, doi: 10.1002/cld.1128

[9] S. Ghosh et al., "Clinical, Laboratory, and Management Profile in Patients of Liver Abscess from Northern India", Journal of Tropical Medicine, vol. 2014, pp. 1-8, 2014, doi: 10.1155/2014/142382

[10] O. Jolobe, "The special case of left lobe amoebic liver abscess", QJM: An International Journal of Medicine, vol. 112, no. 1, pp. 67-68, 2018, doi: 10.1093/qjmed/hcy148

[11] G. Khim, S. Em, S. Mo and N. Townell, "Liver abscess: diagnostic and management issues found in the low resource setting", British Medical Bulletin, vol. 132, no. 1, pp. 45-52, 2019, doi: 10.1093/bmb/ldz032

[12] W. Nan et al., "Differentiation of Liver Abscess from Liver Metastasis using DualEnergy Spectral CT Quantitative Parameters", European Journal of Radiology, vol. 113, pp. 204-208, 2019, doi: 10.1016/j.ejrad.2019.02.024

[13] S. Choi, Y. Kim, J. Min, D. Cha, W. Jeong and W. Lee, "The Value of Gadoxetic Acid-Enhanced MRI for Differentiation between Hepatic Microabscesses and Metastases in Patients with Periampullary Cancer", European Radiology, vol. 27, no. 10, pp. 4383-4393, 2017, doi 10.1007/s00330-017-4782-3

[14] G. Beckers, J. Magema, V. Poncelet and T. Nita, "Successful Laparoscopic Management of A Hepatic Abscess caused by A Fish Bone", Acta Chirurgica Belgica, 
vol. 121, no. 2, pp. 135-138, 2019, doi: 10.1080/00015458.2019.1658353

[15] T. Armstrong, S. Dluzewski and D. Yu, "Appendicitis with Direct Fistulation into the Liver: A Forgotten Cause of Pyogenic Liver Abscess", BJR|case reports, vol. 6, no. 4, p. 20200101, 2020, doi 10.1259/bjrcr.20200101

[16] T. Pham Van, S. Vu Ngoc, N. Nguyen Hoang, D. Hoang Huu and T. Dinh Duong, "Ruptured liver abscess presenting as pneumoperitoneum caused by Klebsiella pneumoniae: a case report", BMC Surgery, vol. 20, no. 1, pp. 1-4, 2020, doi: 10.1186/s12893-020-00858-w

[17] S. Yu-Jang, L. Yen-Chun, L. Yu-Chia and Y. Yu-Hang, "Treatment and Prognosis of Pyogenic Liver Abscess", International Journal of Emergency Medicine, vol. 3, pp. 381-384, 2010, doi: 10.1007/s12245-0100232-6

[18] M. Sarah Abbas and M. Abbas AR, "Laparoscopic Drainage of Liver Abscesses
Case Report and Literature Review", East African Scholars Journal of Medicine and Surgery, vol. 1, no. 4, pp. 114-119, 2019, doi: 10.36349/easjms.2019.v01i04.003

[19] P. Hong Duc et al., "Laparoscopic Surgery for Intra-abdominal Ruptured Liver Abscess: A study of 32 cases", Open Access Journal of Surgery, vol. 10, no. 5, pp. 1-4, 2019, doi: 10.19080/OAJS.2019.10.555798

[20] S. Pais-Costa, S. Araujo and V. Figueiredo, "Hepatectomy for Pyogenic Liver Abscess Treatment: Exception Approach?", $A B C D$. Arquivos Brasileiros de Cirurgia Digestiva (São Paulo), vol. 31, no. 3, pp. 1-5, 2018, doi: 10.1590/0102-672020180001e1394

[21] M. Mogahed, A. Zytoon, B. Eysa, M. Manaa and W. Abdellatif, "Laparoscopic vs Open Drainage of Complex Pyogenic Liver Abscess", World Journal of Laparoscopic Surgery with DVD, vol. 13, no. 1, pp. 11-15, 2020, doi: 10.5005/jpjournals-10033-1395 